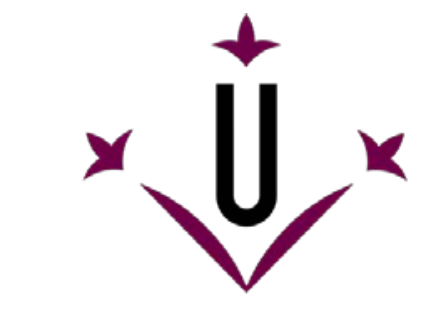

Universitat de Lleida

Document downloaded from:

http://hdl.handle.net/10459.1/62552

The final publication is available at:

https://doi.org/10.2134/agronj2016.09.0537

Copyright

(c) American Society of Agronomy, 2017 


\section{Delayed sowing improved barley yield in a no-till rainfed Mediterranean}

\section{agroecosystem}

\section{Keywords}

Dryland cropping systems; Mediterranean; no-till; sowing date; winter cereals.

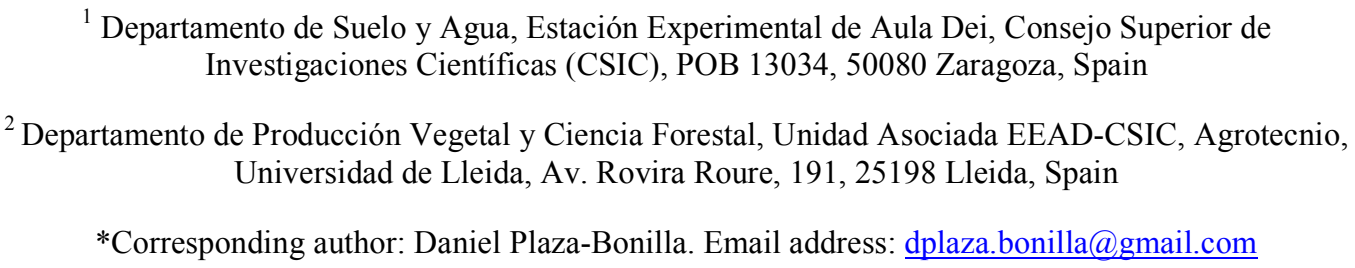

The effect of delaying sowing date and maturity class on no-till barley and soft wheat performance was studied over two periods of three years each. A 3 (sowing date) x 2 (maturity class) randomized complete block (RCB) design was run for 3 years with barley (B-) (2006-7 to 2008-9) and soft wheat (W-) (2009-10 to 2011-12) in NE Spain. Sowing dates corresponded to October (D1 - the standard farming practice), November (D2), and December (D3). Maturity classes corresponded to early (-EC) and medium (MC). Crop above-ground biomass, grain yield and yield components were analyzed. The water-use efficiency of the above-ground biomass and yield (WUE $\mathrm{b}_{\mathrm{b}}$ and $\mathrm{WUE}_{\mathrm{y}}$ ), and nitrogen-use efficiency (NUE), were calculated. Averaging barley maturity classes and cropping seasons, D2 and D3 increased their grain yields 59\% and 46\%, respectively, when compared to D1. A greater number of grains per spike, as well as higher $\mathrm{WUE}_{\mathrm{b}}$ and NUE were observed in D2 and D3 compared to D1 in two of the three 
27 barley cropping seasons. Similarly, a greater thousand kernel weight and higher WUE $_{\mathrm{y}}$

28 was observed when sowing was delayed. Averaged across years, WEC presented a 29 greater yield and above-ground biomass for D2 and D3 compared to D1, while for

30 WMC there were no grain yield differences seen between the sowing dates, above-

31 ground biomass or yield components. Our results demonstrate that, in Western

32 Mediterranean areas, sowing delay under no-till (NT) conditions can increase grain

33 yield, WUE and NUE of winter barley, and also of wheat but only during wet years.

34

35 Abbreviations

36 NT, no-till; NUE, nitrogen use efficiency; TKW, thousand kernel weight, $\mathrm{WUE}_{\mathrm{b}}$, water-

37 use efficiency for above-ground biomass; WUE , water-use efficiency for yield.

39 Core ideas

40 - Sowing delay and cultivar effects on cereal production and water and $\mathrm{N}$ use 41 efficiencies were studied.

42 - Sowing delay increased grain yield due to greater number of grains per m2.

43 - Sowing delay maximized the efficiency in the use of resources 

availability. Rainfall is characterized by strong interannual and seasonal irregularity, being mainly concentrated in the fall and spring. Winter cereals, represented by barley (Hordeum vulgare L.) and wheat (Triticum sp.), are well adapted to Mediterranean conditions given the partial synchronization of their cycle with the period of greatest water availability (Cooper et al., 1987).

The Ebro valley (NE Spain) is a semi-arid area representative of these Mediterranean conditions where rainfed systems have a precipitation gradient from 300 to $700 \mathrm{~mm} \mathrm{yr}^{-1}$. In this area, cropping systems are mainly based on winter cereals since the economic benefit of other winter broadleaf crops such as vetch (Vicia sativa L.) or rapeseed (Brassica napus L.) in severe dryland conditions (with less than $450 \mathrm{~mm}$ of annual rainfall) is doubtful (Álvaro-Fuentes et al., 2009). The choice between barley and wheat depends on the severity of the local climate, barley being better adapted to drier conditions than wheat. This means barley monocrops exist in certain areas, with varying proportions of barley and wheat being found as the climate becomes wetter. Conventionally, farmers in the area sow winter cereals early, just after the first fall rains, around mid-October (both for barley and wheat). One of the reasons for this is to reduce the risk of terminal drought during the grain filling period, common in the Mediterranean areas due to high temperatures and a low soil water content at the end of spring (Loss and Siddique, 1994; González et al., 2007), which in some cases is exacerbated by dry winds (McAneney and Arrúe, 1993). In Australian Mediterranean agriculture, greater grain yield and water-use efficiency have been reported when earlier grain filling occurs (Kirkegaard et al., 2014). Moreover, early sowing leads to vigorous crop establishment under warm conditions (Piggin et al., 2015). However, early sowing of cereals can increase susceptibility to biotic attacks (Thackray et al., 2009) related to 
69 the warm, wet conditions at the beginning of fall in the western Mediterranean region.

70 The main problems for winter cereals in the area include various grasses (e.g. ripgut 71 brome, Bromus diandrus Roth.; annual ryegrass, Lolium rigidum Gaudin), diseases such 72 as Helminthosporium leaf blights (HLB), and insects such as cereal ground beetle 73 (Zabrus tenebrioides Goeze), although only the first have a significant economic 74 impact. Earlier sowing impedes complete mechanical or chemical control of weed 75 seedling emergence and also favors the possibility of earlier pest and disease attacks. 76 Moreover, until a few years ago, for some particular weeds, such as ripgut brome, there 77 were no selective herbicides available for barley. As a consequence, their control in NT systems was based on non-selective pre-sowing herbicides such as glyphosate (N(phosphonomethyl)-glycine), with no control during crop growth. Therefore, in some Mediterranean areas, and in the Ebro valley in particular, winter cereals sown early, 81 especially as monocrops, led to important infestations of this particular brome (García et 82 al., 2014). with the aim of both reducing costs and either maintaining or increasing yields (Cantero-Martínez et al., 2003). The use of long-term NT in semi-arid rainfed conditions leads to greater soil water storage during the previous harvest-to-tillering 87 period and increased precipitation storage efficiency compared with traditional inversion tillage systems based on moldboard ploughing (Lampurlanés et al., 2016).

89 Greater early crop growth has been observed under NT (Santiveri et al., 2004).

90 Similarly, water- and nitrogen-use efficiency are also increased (Angás et al., 2006;

91 Cantero-Martínez et al., 2007). However, early sowing could also increase susceptibility

92 to insects, diseases and weeds under NT. As a consequence, management strategies 93 must be improved in order to overcome the limitations posed by those biotic factors 
94 while reducing the impact of climatic stresses during the grain-filling period as much as 95 possible. To this end, selecting an adequate sowing date and maturity class appear to be 96 key management practices. Moreover, NT bears traffic load better and leads to lower 97 work intensity (Bueno et al., 2006; Soane et al., 2012; Wolf et al., 1989), widening the window of feasible sowing dates to wetter soil conditions.

However, interannual rainfall variability, characteristic of the Mediterranean climate, complicates the selection of an optimum sowing date (Mahdi et al., 1998). For instance, in a Mediterranean area in southern Spain, Ramos et al. (1993) observed greater production of dual-purpose (forage and grain production) triticale when sowing in the last week of November or first week of December compared to earlier sowings. In a study carried out in Syria, Mahdi et al. (1998) studied the effect of different sowing dates on durum wheat grain yield. While in one growing season they observed a $15 \%$ reduction in yield when postponing the November $1^{\text {st }}$ sowing by 15 and 30 days, they observed a $16 \%$ yield increase in the next growing season. However, these last two studies were undertaken under conventional tillage and were only performed over two growing seasons. In the Mediterranean region, choosing a maturity class is another

110 important decision that must be made by farmers. They used to believe that late 111 maturity classes were the best option for higher yields. The interaction between sowing 112 date and maturity class may affect water-use patterns during crop growth: late maturity classes sown earlier tend to use more water due to greater production of biomass during vegetative stages, reducing the availability of this resource during the grain-filling period; in contrast, early maturity classes seeded later may have less pre-anthesis evapotranspiration. This second case could result in a better balance of water-use 117 between the vegetative and reproductive periods in cereals (Connor and Loomis, 1991). 
119 class on grain yield and water- and nitrogen-use efficiency of barley and soft wheat

120 managed under NT conditions. We hypothesized that late sowings and early maturity

121 classes would perform better due to an improved use of soil water and nitrogen. 


\section{Site conditions and experimental design}

124

125

126

127

A field experiment was established in Agramunt (41 $48^{\prime} \mathrm{N}, 1^{\circ} 7^{\prime} \mathrm{E} ; 330 \mathrm{~m}$ asl), NE Spain. The area is representative of dryland semi-arid Mediterranean conditions with a mean annual rainfall of $430 \mathrm{~mm}$, potential evapotranspiration (PET) of $855 \mathrm{~mm}$, and an air temperature of $13.8^{\circ} \mathrm{C}$. The soil was a Typic Xerofluvents (Soil Survey Staff, 2014). The soil water-holding capacity was $185 \mathrm{~mm}$ in the first $90 \mathrm{~cm}$ of depth. Other properties of the Ap horizon $(0-28 \mathrm{~cm})$ included: bulk density: $1.4 \mathrm{~g} \mathrm{~cm}^{-3}$; soil organic carbon: $10.5 \mathrm{~g} \mathrm{~kg}^{-1}$; $\mathrm{pH}\left(\mathrm{H}_{2} \mathrm{O}\right.$ :soil, 1:2.5): 8.5; electrical conductivity (1:5): $0.15 \mathrm{dS} \mathrm{m}^{-1}$; $\mathrm{CaCO}_{3}$ eq. (\%): 40; and loam texture being sand $(2000-50 \mu \mathrm{m})$, silt $(50-2 \mu \mathrm{m})$, and clay $(<2 \mu \mathrm{m})$ content: 475,417 and $118 \mathrm{~g} \mathrm{~kg}^{-1}$, respectively.

Prior to establishing the experiment, the area was devoted to barley production with summer fallow managed under reduced tillage based on two chisel passes. A 3 (sowing date) $\mathrm{x} 2$ (maturity class) randomized complete block (RCB) design was run for 3 years with barley (B-) (2006-7 to 2008-9) and soft wheat (W-) (2009-10 to 2011-12) in NE Spain. Sowing dates corresponded to October (D1 - the standard farming practice), November (D2), and December (D3). Maturity classes corresponded to early (-EC) and medium (-MC). Sowings of the D1 treatment were carried out between October $15^{\text {th }}$ and $20^{\text {th }}$, this treatment being considered a reference as it is typical of the farming regime in the area. D2 was sown between November $5^{\text {th }}$ and $10^{\text {th }}$, and the D3 treatment was sown between November $25^{\text {th }}$ and December $5^{\text {th }}$. In the first period (the 2006-2007, 2007-2008 and 2008-2009 seasons), barley was grown, comparing two maturity classes: Hispanic (barley early maturity class, BEC) and Sunrise (barley medium maturity class, BMC). In the second period (the 2009-2010, 2010-2011 and 2011-2012 growing seasons), two soft wheat maturity classes were compared: Bokaro 
147 (wheat medium maturity class, WMC) and Artur Nick (wheat early maturity class,

148 WEC). These medium and early maturity classes correspond to facultative and spring 149 cultivars, respectively. The experiment was completely randomized in three blocks; 150 individual plot was $6 \mathrm{~m}$ wide $\mathrm{x} 48 \mathrm{~m}$ long. Air temperature and rainfall were recorded 151 hourly using an automated weather station located in the experimental area.

\section{Crop management practices}

The experiment was managed under NT, with the use of a 3 m-wide no-till drill

154

155

156

157

158

159

160

161

162

163

164

165

166

167

168

169

170 with disk openers. Three to five days before sowing, the weeds were controlled by applying $1.5 \mathrm{~L} \mathrm{ha}^{-1}$ of glyphosate ( $\mathrm{N}$-(phosphonomethyl)glycine). The sowing rate was 450 seeds $\mathrm{m}^{-2}$ in rows spaced $17 \mathrm{~cm}$ apart for the two crops studied. In the first two seasons (2006-07 and 2007-08) a post-emergence herbicide treatment with tribenuronmethyl (10 g a.i. ha $\left.{ }^{-1}\right)$ was applied on 15 February in 2007 and on 23 January in 2008 to control broadleaf weeds. In 2008-09, a post-emergence herbicide treatment with a mix of isoproturon plus diflufenican $\left(1243+69 \mathrm{~g}\right.$ a.i. $\left.\mathrm{ha}^{-1}\right)$ was applied on 19 February. In 2009-10, post-emergence weed control (specifically for ripgut brome, Bromus diandrus Roth.) was carried out with mesosulfuron-methyl plus iodosulfuron-methyl-sodium (15 + 3 g a.i. ha ${ }^{-1}$ ) on 5 March. In 2010-11, a post-emergence control of broadleaf and grass weeds was accomplished with tribenuron-methyl plus metsulfuron-methyl $(10+5 \mathrm{~g}$ a.i. $\left.\mathrm{ha}^{-1}\right)$ on 30 March. Mesosulfuron-methyl plus iodosulfuron-methyl-sodium (15 + $3 \mathrm{~g}$ a.i. ha $^{-1}$ ) was applied on 9 February and on 13 April in D1 and D2 and D3, respectively. In 2011-2012 herbicide applications aimed at reducing ripgut brome levels and control broadleaf weeds. Tribenuron-methyl plus metsulfuron-methyl $\left(10+5 \mathrm{~g}\right.$ a.i. $\left.\mathrm{ha}^{-1}\right)$ was applied 20 February while mesosulforon-methyl plus iodosulfuron-methyl-sodium (15+ $3 \mathrm{~g}$ a.i. $\mathrm{ha}^{-1}$ ) was applied on 31 January in D1 and on 13 march in D2 and D3. 
172 stage), at a rate of $50 \mathrm{~kg} \mathrm{~N} \mathrm{ha}^{-1}$, in the form of urea-ammonium nitrate solution $(32 \% \mathrm{~N}$;

173 consisting of $16 \%$ urea-N, $8 \%$ ammonium-N and $8 \%$ nitrate-N) sprayed using stream 174 bars. This rate was decided upon according to the potential grain yield of the site (i.e, $\approx$ $1752.8 \mathrm{Mg} \mathrm{ha}^{-1}$ ), and the annual $\mathrm{N}$ mineralization was estimated to be $30 \mathrm{~kg} \mathrm{~N} \mathrm{ha}^{-1}$ for NT 176 (Angás et al., 2006). Time of application was chosen to minimize $\mathrm{N}$ volatilization 177 losses. Traditionally, farmers of the region applied greater $\mathrm{N}$ rates than the one used in 178 our experiment and carried out pre-sowing applications. However, more than two 179 decades of research carried out in a contiguous experimental area has demonstrated the 180 feasibility to reduce traditional $\mathrm{N}$ rates to a half and the inadequacy of pre-sowing applications given the usually high levels of soil mineral $\mathrm{N}$ before sowing (CanteroMartínez et al., 1995, 2016; Plaza-Bonilla et al., 2017). Crop growth is limited by the low temperatures during the period between sowing and tillering in this Mediterranean 184 region, fact that reduces early $\mathrm{N}$ uptake to a minimum. beginning of July. Crop residues were chopped and uniformly spread over the soil 187 surface.

\section{Soil and crop sampling and measurements}

Soil samples were taken prior to sowing and after harvest in each cropping season studied. In each plot, two representative areas of $2 \times 2 \mathrm{~m}$ were identified and three soil samples per area were taken using a mechanized soil corer, in 30-cm increments, up to a soil depth of $90 \mathrm{~cm}$. Once bulked for each depth, part of the sample was dried at $105^{\circ} \mathrm{C}$ for $48 \mathrm{~h}$ to quantify gravimetric moisture. Soil nitrate was determined by mixing $50 \mathrm{~g}$ of soil with $100 \mathrm{ml}$ of $1 \mathrm{M} \mathrm{KCl}$. The extracts were analyzed using a continuous 
195

196

197

198

199

200

201

202

203

204

205

206

207

208

209

210

211

212

213

214

215

216

217

218

flow autoanalyzer (Seal Autoanalyzer 3, Seal Analytical, Norderstedt, Germany). The soil water and mineral $\mathrm{N}$ content of the entire soil profile $(0-90 \mathrm{~cm})$ were calculated using soil bulk density, measured employing the cylinder method (Grossman and Reinsch, 2002).

The dates of anthesis and physiological maturity were recorded for each treatment and year. Crop above-ground biomass was measured at physiological maturity by cutting the plants at soil level along a $0.5 \mathrm{~m}$ transect of the seeding line in three locations per plot. Once in the laboratory, the heads were separated from the rest of the plant (i.e., leaves and stems); both fractions were then dried at $65^{\circ} \mathrm{C}$ for $48 \mathrm{~h}$ and weighed. After this, in order to calculate the yield components, the ears were counted and threshed and the number of grains and their weight were recorded. These measurements allowed the number of spikes $\mathrm{m}^{-2}$ to be calculated, as well as the number of grains per spike, the thousand kernel weight (TKW), and the harvest index (HI). The grain yield of each treatment was measured by harvesting the plots with a commercial combine, subsequently weighing the grain and taking a sub-sample to standardize the values at $10 \%$ grain moisture.

\section{Calculation of water- and nitrogen-use efficiency}

Water use (WU) during the period between sowing and harvest was calculated as the difference between soil water content $(0-90 \mathrm{~cm}$ soil depth) at the beginning of October and at the harvest of each treatment plus the amount of rainfall received during that period. As in previous works in the same area, water loss as runoff and deep drainage was considered negligible due to the negligible slope $(<2 \%)$ and the severely water-limited conditions (Cantero-Martínez et al., 2007; McAneney and Arrúe, 1993).

The above-ground biomass and grain yield at $10 \%$ moisture were divided by WU to 
219 quantify the agronomic water-use efficiency for above-ground biomass ( $\mathrm{WUE}_{\mathrm{b}}$ ) and 220 water-use efficiency for grain yield $\left(W_{U} E_{y}\right)$, respectively. WUE calculations were 221 based on soil water content in mid-October (right before sowing D1 treatment). This 222 fact could affect WUE values of D2 and D3 treatments if water losses as evaporation 223 between soil sampling and sowing dates were high. However, under Mediterranean 224 conditions, soil water evaporation is minimum during the period between mid-October 225 until February, when soil water recharge takes place (Lampurlanés et al., 2016). Mean 226 PET from 15 October to 5 December (i.e. from D1 sowing date to the latest sowing date 227 of D3 treatment) amounts $62 \mathrm{~mm}$, according to the records of the nearest meteorological 228 station, which only represents a 7\% of mean annual values. Thus, in D2 and D3 the amount of water lost as evaporation would be lower than $62 \mathrm{~mm}$ after discounting the fraction accounting for crop transpiration, and taking into account that soil management was based on no-till, which minimizes soil water evaporation (Unger et al., 1991).

Nitrogen use efficiency was calculated as the ratio of grain yield to $\mathrm{N}$ supply. $\mathrm{N}$ supply was the sum of soil mineral $\mathrm{N}$ at sowing $(0-90 \mathrm{~cm}$ depth), $\mathrm{N}$ applied as fertilizer according to the results obtained by Angás et al. (2006) under similar NT conditions.

\section{Data analysis}

The data are reported in dry wt. per unit area except for yield, which was recorded at $10 \%$ moisture. The data were checked for normality and analyzed using the JMP Pro 11 statistical package (SAS Institute Inc., 2014). Non-normal data was logtransformed for the analysis and back-transformed for its presentation. To compare the

241 effects of cropping season, sowing date, maturity class, and the interaction of these 242 parameters, an analysis of variance (ANOVA) for a randomized block design was 
243 performed for each crop using a general linear model. Differences between treatments 244 were taken to be significant at the 0.05 probability level using a LSD test. Linear 245 relationships between yield components and grain yield were tested using the same 246 software. The slopes of the regressions were tested for differences between sowing 247 dates.

248 


\section{Weather conditions during the experimental period}

251

252

253

254

255

256

257

258

259

260

261

262

263

264

265

266

267

268

269

270

271

272
Air temperatures during the experiment were typical of the Mediterranean region, with cold winters, hot summers, and intermediate values in fall and spring. The fall and winter months showed the lowest temperature range (Fig. 1). Rainfall in the 2006-2007, 2007-2008 and 2008-2009 seasons when barley was cropped was 409, 333 and $528 \mathrm{~mm}$ (Fig. 1a, 1b and 1c). The first two cropping seasons were characterized by dry fall and winter periods, although the 2008-2009 season received $78 \mathrm{~mm}$ more winter rainfall than the historical average (Fig. 1c). However, the three cropping seasons presented greater spring rainfall (233, 219 and $218 \mathrm{~mm}$ for 2006-2007, 2007-2008 and 2008-2009) than the historical value (138 mm), coinciding with the anthesis stage of the crop.

Cumulative rainfall during the three wheat cropping seasons was highly heterogeneous. The $2009-2010$ season was considerably wetter $(703 \mathrm{~mm})$ than the $30-\mathrm{yr}$ average $(430 \mathrm{~mm})$ with significant rainfall values in winter $(303 \mathrm{~mm})$ and spring $(195$ mm) (Fig. 1d). In contrast, the two last cropping seasons analyzed were extremely dry (211 and $228 \mathrm{~mm}$ in the 2010-2011 and 2011-2012 seasons, respectively) (Fig. 1e and 1f). The 2010-2011 season was characterized by a dry summer (42 $\mathrm{mm})$, fall $(1 \mathrm{~mm})$ and winter (45 mm). Similarly, the 2011-2012 season was characterized by dry summer and winter periods, with only $35 \mathrm{~mm}$ and $15 \mathrm{~mm}$, respectively. In 2010-2011 and 20112012, the spring rainfall was 123 and $132 \mathrm{~mm}$, respectively, lower than the $30-\mathrm{yr}$ average (144 mm).

Sowing date and maturity class effects on barley yield and water- and N-use efficiency 
Barley yield and above-ground biomass were significantly affected by the

274 interaction between maturity class and sowing date, and the sowing date $\mathrm{x}$ year and 275 maturity class $\mathrm{x}$ year interactions (Table 1). As an average of the two maturity classes 276 studied, D2 and D3 showed greater barley grain yields than D1 in the three cropping 277 seasons studied (Fig. 2). The greatest grain yield of BEC was observed for D2, while for 278 BMC both D2 and D3 presented greater yields than D1 (Table 1).

279 The number of spikes $\mathrm{m}^{-2}$ was significantly affected by sowing date, maturity class and year main effects but not interactions (Table 1). D1 and D2 showed a greater number of spikes $\mathrm{m}^{-2}$ than D3 as an average of maturity classes and cropping seasons. The number of grains per spike was significantly affected by the sowing date $\mathrm{x}$ year and maturity class $\mathrm{x}$ year interactions. An increased number of grains per spike was observed when the sowing date was delayed in 2006-2007 and 2008-2009, while in 2007-2008 the D2 treatment showed the greatest values (Fig. 2). Moreover, BMC had a greater number of grains per spike than BEC in the three cropping seasons. The TKW was significantly affected by all main effects and their interactions. Increased TKW was observed when the date of sowing was delayed in the three cropping seasons, with the exception of 2008-2009 for BEC (Fig. 2). The harvest index was affected by all the effects and their interactions, except the interaction between sowing date and maturity class (Table 1). Delaying sowing (D2 and D3 compared to D1) led to higher HI in 20062007 for both maturity classes (BMC and BEC) and in 2007-2008 for BMC (Fig. 2). However, that trend was not observed in 2008-2009. sowing date $(P=0.005)$ (data not shown). Significant differences in WU between sowing dates were only observed in 2006-2007 with lower values for D1 compared to 
298

299

300

301

302

303

304

305

306

307

308

309

310

311

312

313

314

315

316

317

318

319

320

321

sowing date $\mathrm{x}$ year and maturity class $\mathrm{x}$ year interactions. $\mathrm{WUE}_{\mathrm{y}}$ was also affected by the interaction between sowing date and maturity class, and by the triple interaction (Table 1). Greater $\mathrm{WUE}_{\mathrm{b}}$ was observed in D2 and D3 compared to D1 in 2006-2007 and 2008-2009 as an average of maturity classes, while D2 showed the highest values in 2007-2008 (Fig. 2). The $\mathrm{WUE}_{\mathrm{y}}$ of BMC and BEC increased significantly when the sowing date was delayed from D1 to D2 and D3 (Fig. 2).

Barley NUE was significantly affected by the sowing date $\mathrm{x}$ maturity class, sowing date $\mathrm{x}$ year as well as maturity class $\mathrm{x}$ year interactions (Table 1). NUE increased significantly when the sowing date was delayed from D1 to D2 and D3 in 2006-2007 and 2008-2009, as an average of maturity class (Fig. 2). When distinguishing between maturity classes, the delay of sowing date (D2 and D3 compared to D1) also significantly increased barley NUE (Table 1).

\section{Sowing date and maturity class effects on wheat yield and water- and N-use efficiency}

Wheat grain yield was significantly affected by maturity class $\mathrm{x}$ sowing date, sowing date $\mathrm{x}$ year, as well as maturity class $\mathrm{x}$ year interactions (Table 2). Wheat aboveground biomass was significantly affected by the interaction between sowing date and year, and by the interaction between maturity class and year (Table 2). In 2009-2010 the delay of sowing led to an increase in grain yield and above-ground biomass, while the contrary result was observed in 2010-2011 and 2011-2012 (Fig. 3). The delay of sowing only positively affected the grain yield of WEC as an average of the three cropping seasons studied (Table 2).

The three wheat yield components studied were significantly affected by the interaction between sowing date and year (Table 2). In 2009-2010 the delay of sowing 
322 led to greater number of spikes $\mathrm{m}^{2}$ and grains per spike, but had no effect on TKW (Fig. 323 3). In contrast, in the 2010-2011 and 2011-2012 seasons lower TKW was observed 324 when sowing was delayed, while in 2010-2011 the delay of sowing led to a lower 325 number of grains per spike (Fig. 3). The wheat HI was significantly affected by the 326 interaction between sowing date and maturity class, and the interaction between sowing 327 date and year (Table 2). However, a delay in sowing produced no consistent trend in 328 this variable.

Wheat WU was only affected by year $(\mathrm{P}<0.001)$ with 2009-2010 > 2011-2012 $>$ 2010-2011 (data not shown). Wheat $\mathrm{WUE}_{\mathrm{b}}$ was affected by the interaction between maturity class and year, and the interaction between sowing date and year (Table 2). In turn, $\mathrm{WUE}_{\mathrm{y}}$ was affected by year $\mathrm{x}$ sowing date interaction. The delay in sowing had contrary effects on $\mathrm{WUE}_{\mathrm{b}}$ and $\mathrm{WUE}_{\mathrm{y}}$ depending on the cropping season. Thus, while D2 and D3 showed higher $\mathrm{WUE}_{\mathrm{b}}$ and $\mathrm{WUE}_{\mathrm{y}}$ values than D1 in 2009-2010, the opposite trend was observed in 2010-2011 and 2011-2012 (Fig. 3). Wheat NUE was affected by maturity class and the interaction between sowing date and year (Table 2). Compared to D1, later sowing dates (i.e., D2 and D3) led to increased NUE in the 2009-2010 cropping season (Fig. 3). Moreover, greater NUE was observed in WMC than in WEC as an average of cropping seasons (Table 2). between grain yield and the number of spikes $\mathrm{m}^{2}$, no significantly different between 342 them at $P<0.05$. Contrarily, no relationship was found in D1 (Fig. 4a) $(\mathrm{P}=0.76)$. As a 343 difference, the three barley sowing dates $(\mathrm{D} 1, \mathrm{D} 2$ and D3) showed the same $(\mathrm{P}<0.05)$ 344 linear relationship between the number of grains per spike and grain yield (Fig. 4b). No 345 relationship was found between TKW and barley grain yield $(\mathrm{P}=0.17)$. In the case of 346 wheat, grain yield was linearly related to the number of spikes $\mathrm{m}^{2}$ and to the number of 
347 grains per spike, with no differences between sowing dates according to the analysis of 348 covariance performed (Fig. 4d, 4e). In contrast, wheat TKW showed a non-significantly 349 different linear relationship with grain yield between D2 and D3, while no relationship 350 was found for D1 at $P<0.05$ (Fig. 4f). 

components

The delay of sowing date had a positive influence on grain yield in the three

356

357 seasons cropped with barley, and in the first season cropped with wheat (a wet year). The improved performance of barley in $2 / 3$ years and wheat in $1 / 3$ years from delayed sowing dates in the rainfed semi-arid conditions of the experiment could be explained by a better synchronization between water use and crop requirements. Rainfall distribution during the growing season and water storage during summer fallow play a major role on winter cereal production in dryland Mediterranean areas (Basso et al., 2012; Sadras et al., 2012; Lampurlanés et al., 2016). The lower number of grains per spike and TKW in D1 indicates increased water deficit when these yield components were determined compared to the later sowings. García del Moral et al. (2003) pointed out that under poor conditions a reduced tillering rate can become a useful trait for conserving resources that are more efficiently used during the critical phases of yield determination. Terminal drought represents one of the key factors in yield reduction in water-limited areas (González et al., 2007).

The increased number of grains per spike and TKW in the three seasons of barley and the first season of wheat, observed for D2 and D3, could also have been favored by the rainfall received during the late spring, in similar or greater quantities than the historical average, which is better used by crops. Late spring rains often occur in western Mediterranean regions. The increased number of grains per spike and greater TKW would explain the greater barley harvest index in the 2006-2007 and 2007-2008 seasons for the D2 and D3 sowing dates. In contrast, in the 2008-2009 season there was 
376

377

378

379

380

381

382

383

384

385

more rainfall during the fall, which significantly enhanced the production of aboveground barley biomass in D2 and D3 and slightly reduced the HI.

In Mediterranean areas with colder fall conditions than those in our experiment greater yields have been reported at earlier sowing dates due to a longer season (Richards et al., 2014; Stephens and Lyons, 1998). However, according to our results, in regions with a mild fall this general assumption does not apply. In this regard, as our data suggest, the use of longer maturity classes of barley (i.e. BMC vs. BEC) at an early sowing date could lead to a water deficit during the grain filling period, resulting in lower TKW and reducing crop yields. Interestingly, the opposite was found to be true for wheat, where a lower yield was observed in WEC compared to WMC as an average of cropping seasons. This result could be explained by the erratic nature of spring rainfall which defines a narrow and highly variable window of late water available to crops, favoring different maturity classes depending on the cropping season.

Uunder the western Mediterranean conditions of the experiment the first half of fall presents warm temperatures that do not limit the development of certain pathogens and weeds. At the experimental site, the 30-yr air temperature averages for October and November are 14.5 and $7.9{ }^{\circ} \mathrm{C}$, respectively. The use of NT combined with the early sowing of cereal monocrops favor the development of small-seeded grasses such as ripgut brome. During the experimental period no active ingredients were commercially available for the post-emergence control of this weed under barley production, relying solely on non-selective pre-sowing herbicides (glyphosate). However, this herbicide is more effective for delayed sowing dates since (i) the window of weed emergence during fall rains is longer, and (ii) wetter soil conditions favor glyphosate uptake by weeds. In our experiment, García et al. (2014) measured ripgut brome density in the 2008-2009, 2009-2010 and 2010-2011 seasons at herbicide applications. For the D1, D2 and D3 
401 sowing dates ripgut brome density was recorded as 540,105 and 32 plants $\mathrm{m}^{-2}$ in 2008-

402 2009; 1284, 27 and 9 plants $\mathrm{m}^{-2}$ in 2009-2010; and 102, 3 and 1 plants $\mathrm{m}^{-2}$ in 2010-2011

403 (García et al., 2014). Thus, the greater yields reached in D2 and D3 compared to D1 in

404 the three seasons of barley and in the first year of wheat could be also partly explained

405 by less competition with weeds for water. In the case of wheat, the competition between

406 the crop and weeds would have been lower in subsequent seasons (2010-11 and 2011-

407 12) given the application of a selective herbicide to control ripgut brome which reduced

408 significantly the seedbank of this weed as García et al. (2014) showed.

Sowing date delay and maturity class effects on water- and nitrogen-use efficiency

410 In the case of barley, WU only differed between sowing dates for the 2006-2007

411 harvest, with lower values for D1. Lower biomass was caused by reduced water uptake.

412 Therefore, increased WUE in D2 and D3 was the result of increased biomass. However,

413 in the case of wheat, which has a longer development period than barley, cultivars sown

414 at delayed dates may reduce $\mathrm{WUE}_{\mathrm{y}}$ and NUE as a result of a water deficit during the

415 grain filling period. This latter aspect appears to be corroborated by the decreased wheat

416 WUE $_{\mathrm{y}}$ observed in D3 in the 2010-2011 season, as well as in D2 and D3 in the 2011-

4172012 season, when there was an important water deficit for much of the growing cycle.

418 Compared to $2009-10$, there was a $57 \%$ and $53 \%$ reduction in WU in 2010-2011 and

419 2011-2012, which led to a strong diminution in the yield components. In severely water-

420 limited western Mediterranean areas, farmers tend to favor barley over wheat, given the

421 shorter cycle of the former, aiming at reducing terminal drought effects as much as

422 possible (Ryan et al., 2008). Our data corroborates that late wheat sowings perform 423 poorly in very dry years. 
Soil mineral $\mathrm{N}$ at sowing and $\mathrm{N}$ use did not differ significantly between

425

426

427

428

429

430

431

432

433

434

435

436

437

438

439

440

441

442

443

444

445

446

447

448

treatments during the barley cropping seasons. However, a lower mineral $\mathrm{N}$ content at sowing would be expected for the most productive sowing dates, resulting from increased $\mathrm{N}$ uptake. The observed result could be the consequence of greater $\mathrm{N}$ uptake by grass weeds in D1. The role played by other processes in the $\mathrm{N}$ cycle, mainly losses, would be secondary. In average years, well-managed Mediterranean dryland agroecosystems lose little $\mathrm{N}$ through leaching and denitrification. Regarding to this, in a contiguous experiment managed under NT and similar rates of $\mathrm{N}$, Plaza-Bonilla et al. (2014) reported a loss of $\mathrm{N}$ of less than $0.5 \mathrm{~kg} \mathrm{~N}_{2} \mathrm{O}-\mathrm{N} \mathrm{yr}{ }^{-1}$. According to Angás et al. (2006) the area presents highly unusual rainfall conditions for leaching, which occurs once every 7-10 years. However, $\mathrm{N}$ losses by volatilization can be very high in specific cases (Sanz-Cobena et al., 2008). Despite ammonia volatilization could have been a major loss pathway given the $\mathrm{pH}$ of the soil of the experiment and the type of fertilizer used, the use of urea-ammonium nitrate solutions in the area has become a common farmers' practice in the area given it is cheaper, easy to use and it gives the possibility to mix the tank with pesticides. Therefore, as Angás et al. (2006) suggested, the development of injection techniques would be a valuable way to improve the efficiency of fertilizer.

The two-fold increase in barley NUE values in 2008-2009, characterized by a wet spring, demonstrates the principal role played by water availability at the end of the season in the more efficient use of nitrogen. However, this result could also be partially explained by the lower amount of mineral $\mathrm{N}$ available at sowing, which was 266,179 and $94 \mathrm{~kg} \mathrm{~N} \mathrm{ha}^{-1}$ for the 2006-2007, 2007-2008 and 2008-2009 seasons, as an average of the treatments. The decreased soil $\mathrm{N}$ availability resulted from the lower quantities of mineral $\mathrm{N}$ rate applied during the experiment (i.e. $50 \mathrm{~kg} \mathrm{~N} \mathrm{ha}^{-1}$ ) compared with the rate 
449

450

451

452

453

454

455

456

457

458

459

460

461

462

463

464

465

466

467

468

469

470

471

applied by the farmer (double or more in some cases). In our experiment that rate was established in order to achieve a soil status that was less susceptible to $\mathrm{N}$ losses to the environment.

Wheat maturity class choice played a major role in $\mathrm{WUE}_{\mathrm{y}}$ and NUE. The shorter cycle of WEC than WMC could have reduced the susceptibility to terminal drought, increasing $\mathrm{WUE}_{\mathrm{y}}$ and NUE.

\section{CONCLUSIONS}

No-till farming is an increasingly adopted soil management practice in semi-arid dryland areas. Among other benefits, it facilitates the delay of cereal sowing date due to improved trafficability, widening the window for sowing and partly avoiding mild temperatures in the western Mediterranean that increase susceptibility to pests, weeds and diseases. In our work, the delay of sowing (from October to mid-November and beginning of December) increased yield in years with normal (or greater than normal) rainfall, 2/3 years in barley and 1/3 years in wheat. The increased water availability in later stages when delaying sowing led to better conditions for defining the number of grains per spike and the TKW. Delayed sowing in average years maximized resource use efficiency for water and nitrogen, increasing the sustainability of the system. However, in years with extreme drought conditions (such as 2010-2011 and 2011-2012 in our experiment), the delay in sowing increased susceptibility to terminal drought, negatively affecting the TKW and reducing grain yield. Although we only compared two cultivars of each species, the data suggests that the best combination of sowing date and maturity class is highly dependent on the erratic rainfall during late spring.

\section{Acknowledgements}


472 This work was supported by the Comisión Interministerial de Ciencia y 473 Tecnología of Spain (Project Grants AGL2007-66320-C02-01/AGR and AGL2010474 22050-C03-01). DPB received a "Juan de la Cierva-Formación” postdoctoral grant 475 from the Ministerio de Economía y Competitividad of Spain (ref. FJCI-2014-19570). 476 We thank Silvia Martí, Carlos Cortés and Miquel Betriu for their technical assistance. 


\section{REFERENCES}

478 Álvaro-Fuentes, J., J. Lampurlanés, and C. Cantero-Martínez. 2009. Alternative crop 479 rotations under Mediterranean no-tillage conditions: biomass, grain yield, and $480 \quad$ water-use efficiency. Agron. J. 101:1227-1233.

481 Angás, P., J. Lampurlanés, and C. Cantero-Martínez. 2006. Tillage and N fertilization 482 effects on $\mathrm{N}$ dynamics and barley yield under semiarid Mediterranean conditions. $483 \quad$ Soil \& Till. Res. 87:59-71.

484

485

486

487

488

489

490

491

492

493

494

495

496

497

498

Basso, B., C. Fiorentino, D. Cammarano, G. Cafiero, and J. Dardanelli. 2012. Analysis of rainfall distribution on spatial and temporal patterns of wheat yield in Mediterranean environment. Eur. J. Agron. 41:52-65.

Bueno, J., C. Amiama, J.L. Hernanz, and J.M. Pereira. 2006. Penetration resistance, soil water content, and workability of grassland soils under two tillage systems. T. ASABE 49:875-882.

Cantero-Martínez, C., P. Angás, and J. Lampurlanés. 2003. Growth, yield and water productivity of barley (Hordeum vulgare L.) affected by tillage and $\mathrm{N}$ fertilization in Mediterranean semiarid, rainfed conditions of Spain. Field Crop Res. 84:341-357.

Cantero-Martínez, C., P. Angás, and J. Lampurlanés. 2007. Long-term yield and water use efficiency under various tillage systems in Mediterranean rainfed conditions. Ann. Appl. Biol. 150:293-305.

Cantero-Martínez, C., D. Plaza-Bonilla, P. Angás, and J. Álvaro-Fuentes. 2016. Best management practices of tillage and nitrogen fertilization in Mediterranean rainfed conditions: Combining field and modelling approaches. Eur. J. Agron. 79:119-130. 
499 Cantero-Martínez, C., J.M. Villar, I. Romagosa, and E. Fereres. 1995. Nitrogen 500 fertilization of barley under semi-arid rainfed conditions. Eur. J. Agron. 4:309-316.

501 Connor, D.J., and R.S. Loomis. 1991. Strategies and tactics for water-limited agriculture 502 in low rainfall Mediterranean climates. In: Acevedo, E., C. Giménez, E. Fereres, and 503 J.P. Srivastrava. (Eds). Improvement and management of winter cereals under 504 temperature, drought and salinity stresses. Proceedings of the ICARDA-INIA 505 Symposium, Madrid, Spain, pp. 441-465.

506 Cooper, P.J.M., P.J. Gregory, D. Tully, and H.C. Harris. 1987. Improving water-use 507 efficiency of annual crops in the rain-fed farming systems of West Asia and North$508 \quad$ Africa. Exp. Agr. 23:113-158.

509 García, A.L., J. Torra, A. Royo-Esnal, C. Cantero-Martinez, and J. Recasens. 2014. 510 Integrated management of Bromus diandrus in dryland cereal fields under no-till. $511 \quad$ Weed Res. 54:408-417.

512 García del Moral, L.F., M.B. García del Moral, J.L. Molina-Cano, and G.A. Slafer. 5132003 . Yield stability and development in two- and six-rowed winter barleys under 514 Mediterranean conditions. Field Crop Res. 81:109-119.

515 González, A., I. Martín, and L. Ayerbe. 2007. Response of barley genotypes to terminal 516 soil moisture stress: phenology, growth and yield. Aust. J. Agr. Res. 58:29-37.

517 Grossman, R.B., and T.G. Reinsch. 2002. Bulk density and linear extensibility. In: 518 Dane, J.H., and G.C. Topp. (Eds) Methods of soil analysis. Part 4. Physical 519 methods. SSSA Book Ser. 5. SSSA, Madison, pp 201-228

520 Kirkegaard, J.A., J.R. Hunt, T.M. McBeath, J.M. Lilley, A. Moore, K. Verburg, M. 521 Robertson, Y. Oliver, P.R. Ward, S. Milroy, and A.M. Whitebread. 2014. Improving 
522 water productivity in the Australian grains industry - a nationally coordinated $523 \quad$ approach. Crop Pasture Sci. 65:583-601

524 Lampurlanés, J., D. Plaza-Bonilla, J. Álvaro-Fuentes, and C. Cantero-Martínez. 2016. 525 Long-term analysis of soil water conservation and crop yield under different tillage 526 systems in Mediterranean rainfed conditions. Field Crop Res. 189:59-67. DOI: $527 \quad$ 10.1016/j.fcr.2016.02.010.

528 Loss, S.P., and K.H.M. Siddique. 1994. Morphological and physiological traits 529 associated with wheat yield increases in Mediterranean environments. Adv. Agron. $530 \quad 52: 229-276$.

531 Mahdi, L., C.J. Bell, and J. Ryan. 1998. Establishment and yield of wheat (Triticum 532 turgidum L.) after early sowing at various depths in a semi-arid Mediterranean 533 environment. Field Crop Res. 58:187-196.

534 McAneney, K.J., and J.L. Arrúe, J.L. 1993. A wheat-fallow rotation in northeastern 535 Spain: water balance-yield considerations. Agronomie 13:481-490.

536 Piggin, C., A. Haddad, Y. Khalil, S. Loss, and M. Pala. 2015. Effects of tillage and time 537 of sowing on bread wheat, chickpea, barley and lentil grown in rotation in rainfed $538 \quad$ systems in Syria. Field Crop Res. 173:57-97.

539 Plaza-Bonilla, D., J. Álvaro-Fuentes, J.L. Arrúe, and C. Cantero-Martínez. 2014. Tillage 540 and nitrogen fertilization effects on nitrous oxide yield-scaled emissions in a rainfed 541 Mediterranean area. Agric. Ecosys. Environ. 189:43-52.

542 Plaza-Bonilla, D., C. Cantero-Martínez, J. Bareche, J.L. Arrúe, J. Lampurlanés, and J. 543 Álvaro-Fuentes. 2017. Do no-till and pig slurry application improve barley yield and 

water and nitrogen use efficiencies in rainfed Mediterranean conditions? Field Crop Res. 203:74-85.

546

547

548

549

550

551

552

553

554

555

556

557

558

559

560

561

562

563

564

565

566

Ramos, J.M., M.B. García del Moral, J. Marinetto, and L.F. García del Moral. 1993. Sowing date and cutting frequency effects on triticale forage and grain production. Crop Sci. 33:1312-1315.

Richards, R.A., J.R. Hunt, J.A. Kirkegaard, and J.B. Passioura. 2014. Yield improvements and adaptation of wheat to water-limited environments in Australia-a case study. Crop Pasture Sci. 65:676-689.

Ryan, J., M. Singh, and M. Pala. 2008. Long-term cereal-based rotation trials in the Mediterranean region: implications for cropping sustainability. Adv. Agron. 97:273319.

Sadras, V.O., C. Lawson, P. Hooper, and G.K. Mc Donald. 2012. Contribution of summer rainfall and nitrogen to the yield and water use efficiency of wheat in Mediterranean-type environments of South Australia. Eur. J. Agron. 36:41-54.

Santiveri, F., J. Lloveras, S. Martí and C. Cantero-Martínez. 2004. Crop emergence and early crop growth of barley affected by crop residue under different tillage systems and $\mathrm{N}$ fertilization rates in semiarid conditions of Northeast Spain. In: Cantero, C. and D. Gabiña (eds.). Mediterranean rainfed agriculture: strategies for sustainability. Options Mediterranées. Vol. 60: 63-72. ISBN: 2-85352-294-6.

Sanz-Cobena, A., T.H. Misselbrook, A. Arce, J.I. Mingot, J.A. Diez, and A. Vallejo. 2008. An inhibitor of urease activity effectively reduces ammonia emissions from soil treated with urea under Mediterranean conditions. Agric. Ecosys. Environ. 126:243-249. 
567 SAS Institute Inc,. 2014. Using JMP1 11, Second edition SAS Institute Inc., Cary, NC.

568 Soane, B.D., B.C. Ball, J. Arvidsson, G. Basch, F. Moreno, and J. Roger-Estrade. 2012.

569 No-till in northern, western and south-western Europe: A review of problems and 570 opportunities for crop production and the environment. Soil Till. Res. 118:66-87.

571 Soil Survey Staff. 2014. Keys to Soil Taxonomy, 12th ed. USDA-Natural Resources 572 Conservation Service, Washington, DC.

573 Stephens, D.J., and T.J. Lyons. 1998. Variability and trends in sowing dates across the $574 \quad$ Australian wheatbelt. Aust. J. Agric. Res. 49:1111-1118.

575 Thackray, D.J., A.J. Diggle, and R.A.C. Jones. 2009. BYDV PREDICTOR: a 576 simulation model to predict aphid arrival, epidemics of Barley yellow dwarf virus 577 and yield losses in wheat crops in Mediterranean-type environment. Plant Pathol. $578 \quad 58: 186-202$.

579 Unger, P.W., Stewart, B.A., Parr, J.F., and R.P. Singh. 1991. Crop residue management 580 and tillage methods for conserving soil and water in semi-arid regions. Soil Till. 581 Res. 20:219-240.

Wolf, D.D., and K.L. Edmisten. 1989. Late season alfalfa plantings: conventional vs. 583 no-till methods. Crop Sci. 29:170-175. 


\section{Figure captions}

585 Fig. 1 Weekly precipitation (columns), and average maximum (black circles) and 586 minimum (white circles) temperatures at the Agramunt experimental site: 30-yr average 587 and cropping seasons studied (from 2006-2007 to 2008-2009 for barley and from 20095882010 to 2011-2012 for wheat). At the top of each sub-figure the grey-edged symbols 589 indicate the dates of sowing, anthesis and physiological maturity for the D1 (circles), 590 D2 (triangles) and D3 (squares) sowing dates and for the early- (black-filled symbols) 591 and medium (empty symbols) maturity classes. Note the different Y-axes.

592 Fig. 2 Barley grain yield, above-ground biomass, spikes $\mathrm{m}^{-2}$, grains spike ${ }^{-1}$, thousand 593 kernel weight (TKW), harvest index, water-use efficiency for biomass and yield (WUE 594 and $\mathrm{WUE}_{\mathrm{y}}$ ) and nitrogen-use efficiency (NUE) during the 2006-2007, 2007-2008 and 595 2008-2009 cropping seasons as affected by sowing date (D1-October, D2-November, 596 and D3-December) and maturity class (medium, BMC; early, BEC). Vertical bars 597 indicate standard deviation. For a given year, different lower-case letters indicate 598 significant differences between sowing dates and maturity classes. For a given year, 599 different lower-case italic letters and different upper-case letters indicate significant 600 differences between sowing dates and maturity classes, respectively ( $P<0.05$, LSD test).

601 Fig. 3 Wheat grain yield, above-ground biomass, spikes $\mathrm{m}^{-2}$, grains spike ${ }^{-1}$, thousand 602 kernel weight (TKW), harvest index, water-use efficiency for biomass and yield (WUE 603 and $\mathrm{WUE}_{\mathrm{y}}$ ) and nitrogen-use efficiency (NUE) during the 2009-10, 2010-11 and 201160412 cropping seasons as affected by sowing date (D1-October, D2-November, and D3605 December) and maturity class (medium, WMC; early, WEC). Vertical bars indicate 606 standard deviation. For a given year, different lower-case letters indicate significant 607 differences between sowing dates and maturity classes. For a given year, different 608 lower-case italic letters and different upper-case letters indicate significant differences 609 between sowing dates and maturity classes, respectively $(P<0.05$, LSD test).

610 Fig. 4 Linear relationship between grain yield and spikes $\mathrm{m}^{-2}$, grains spike $^{-1}$ and 611 thousand kernel weight (TKW) of barley (a, b and c, respectively) and wheat ( $\mathrm{d}$, e and f, 612 respectively) as affected by sowing date (D1-October, D2-November, and D3613 December). Each legend shows the sowing dates with the same significant linear 
614 relationship at $P<0.05$. Non-significant linear relationships are not shown. Note the 615 different axes. 
616 Table 1 Analysis of variance of barley grain yield, above-ground biomass, spikes $\mathrm{m}^{-2}$, grains spike ${ }^{-1}$, thousand kernel weight (TKW), harvest 617 index (HI), water-use efficiency for above-ground biomass (WUE $\mathrm{b}_{\mathrm{b}}$ ) and grain yield (WUE $)_{\mathrm{y}}$, and nitrogen use efficiency (NUE) as affected by 618 sowing date (D1, October; D2, November, and D3, December), maturity class (BEC and BMC, barley early and medium maturity class, 619 respectively) and year, and their interactions.

\begin{tabular}{|c|c|c|c|c|c|c|c|c|c|}
\hline $\begin{array}{l}\text { Treatments and } \\
\text { ANOVA effects }\end{array}$ & Grain yield & Abg. biomass & Spikes $\mathbf{m}^{-2}$ & Grains spike $^{-1}$ & TKW & HI & $\mathbf{W U E}_{\mathbf{b}}$ & $\mathbf{W U E}_{\mathbf{y}}$ & NUE \\
\hline & -- $\mathrm{kg} \mathrm{ha}^{-1}--$ & $--\mathrm{g} \mathrm{m}^{-2}--$ & & & -- g-- & & -- $\mathrm{kg} \mathrm{ha}^{-1} \mathrm{~mm}^{-1}-{ }^{-}$ & $--\mathrm{kg} \mathrm{ha}^{-1} \mathrm{~mm}^{-1}-$ & -- $\mathrm{kg} \mathrm{ha}^{-1} \mathrm{~kg} \mathrm{~N}^{-1}--$ \\
\hline D1 (October) & $2481 \mathrm{c} \dagger$ & $792 \mathrm{~b}$ & $843 \mathrm{a}$ & $12 \mathrm{~b}$ & $35.0 \mathrm{c}$ & $0.46 \mathrm{~b}$ & $20.4 \mathrm{~b}$ & 6.4 & $10.8 \mathrm{~b}$ \\
\hline D2 (November) & 3946 a & 1029 a & $895 \mathrm{a}$ & $15 \mathrm{a}$ & $38.5 \mathrm{~b}$ & $0.50 \mathrm{a}$ & $26.2 \mathrm{a}$ & 10.0 & $17.1 \mathrm{a}$ \\
\hline D3 (December) & $3623 \mathrm{~b}$ & $949 \mathrm{a}$ & $729 b$ & $16 \mathrm{a}$ & $40.5 \mathrm{a}$ & $0.51 \mathrm{a}$ & $23.7 \mathrm{a}$ & 8.9 & $14.4 \mathrm{a}$ \\
\hline $\mathrm{BEC}$ & 3336 & 897 & $888 \mathrm{a}$ & $13 \mathrm{~b}$ & $41.1 \mathrm{a}$ & $0.50 \mathrm{a}$ & 22.8 & 8.4 & $14.4 \mathrm{a}$ \\
\hline $\mathrm{BMC}$ & 3364 & 957 & $757 \mathrm{~b}$ & $17 \mathrm{a}$ & $35.0 \mathrm{~b}$ & $0.47 \mathrm{~b}$ & 24.1 & 8.7 & $13.8 \mathrm{~b}$ \\
\hline 2006-07 & $3418 b$ & $1011 \mathrm{a}$ & $1034 \mathrm{a}$ & $14 \mathrm{~b}$ & $31.0 \mathrm{~b}$ & $0.43 \mathrm{c}$ & $29.5 \mathrm{a}$ & 9.9 & $9.9 \mathrm{~b}$ \\
\hline $2007-08$ & $2519 \mathrm{a}$ & $660 \mathrm{~b}$ & $625 \mathrm{c}$ & $14 \mathrm{~b}$ & $41.3 \mathrm{a}$ & $0.53 \mathrm{a}$ & $18.6 \mathrm{~b}$ & 7.3 & $9.8 \mathrm{~b}$ \\
\hline 2008-09 & $4113 \mathrm{c}$ & $1092 \mathrm{a}$ & $808 \mathrm{~b}$ & $16 \mathrm{a}$ & $41.8 \mathrm{a}$ & $0.50 \mathrm{~b}$ & $22.3 \mathrm{~b}$ & 8.4 & $24.2 \mathrm{a}$ \\
\hline D1-BEC & $2635 \mathrm{c}$ & $779 \mathrm{~d}$ & 942 & 10 & $38.7 \mathrm{c}$ & 0.47 & 20.4 & $6.7 \mathrm{~d}$ & $12.6 \mathrm{~b}$ \\
\hline D2-BEC & $3892 \mathrm{a}$ & 929 bc & 940 & 13 & $40.5 \mathrm{~b}$ & 0.51 & 23.7 & $9.7 \mathrm{ab}$ & $17.4 \mathrm{a}$ \\
\hline D3-BEC & $3481 \mathrm{~b}$ & $982 \mathrm{~b}$ & 783 & 14 & $44.1 \mathrm{a}$ & 0.53 & 24.3 & $8.7 \mathrm{c}$ & $12.8 \mathrm{a}$ \\
\hline D1-BMC & $2326 \mathrm{~d}$ & $806 \mathrm{~cd}$ & 745 & 15 & $31.4 \mathrm{e}$ & 0.45 & 20.5 & $6.1 \mathrm{~d}$ & $9.0 \mathrm{c}$ \\
\hline D2-BMC & $4001 \mathrm{a}$ & $1130 \mathrm{a}$ & 851 & 17 & $36.5 \mathrm{~d}$ & 0.48 & 28.8 & $10.3 \mathrm{a}$ & $16.8 \mathrm{a}$ \\
\hline D3-BMC & $3765 \mathrm{a}$ & $917 \mathrm{bcd}$ & 675 & 18 & $36.9 \mathrm{~d}$ & 0.49 & 23.1 & $9.1 \mathrm{bc}$ & $15.9 \mathrm{a}$ \\
\hline \multicolumn{5}{|c|}{$A N O V A$} & \multicolumn{5}{|c|}{$P$-values } \\
\hline Sowing date (SD) & $<0.001$ & $<0.001$ & 0.006 & $<0.001$ & $<0.001$ & $<0.001$ & $<0.001$ & $<0.001$ & $<0.001$ \\
\hline Maturity class (C) & 0.728 & 0.133 & 0.003 & $<0.001$ & $<0.001$ & $<0.001$ & 0.370 & 0.313 & 0.012 \\
\hline Year $(\mathrm{Y})$ & $<0.001$ & $<0.001$ & $<0.001$ & 0.003 & $<0.001$ & $<0.001$ & $<0.001$ & $<0.001$ & $<0.001$ \\
\hline $\mathrm{SD} \times \mathrm{C}$ & 0.013 & 0.037 & 0.513 & 0.505 & $<0.001$ & 0.447 & 0.055 & 0.014 & 0.007 \\
\hline $\mathrm{SD} \times \mathrm{Y}$ & $<0.001$ & $<0.001$ & 0.095 & $<0.001$ & $<0.001$ & $<0.001$ & 0.009 & $<0.001$ & $<0.001$ \\
\hline C x Y & $<0.001$ & 0.003 & 0.133 & 0.003 & $<0.001$ & $<0.001$ & 0.049 & $<0.001$ & $<0.001$ \\
\hline $\mathrm{SD} \times \mathrm{C} \times \mathrm{Y}$ & 0.078 & 0.014 & 0.373 & 0.881 & 0.010 & $<0.001$ & 0.182 & 0.002 & 0.120 \\
\hline
\end{tabular}


622 Table 2 Analysis of variance of wheat grain yield, above-ground biomass, spikes $\mathrm{m}^{-2}$, grains spike ${ }^{-1}$, thousand kernel weight (TKW), harvest index $(\mathrm{HI})$, water-use efficiency for above-ground biomass $\left(\mathrm{WUE}_{\mathrm{b}}\right)$ and grain yield (WUE $\mathrm{W}_{\mathrm{y}}$ ), and nitrogen use efficiency (NUE) as affected by sowing date (D1, October; D2, November, and D3, December), maturity class (WEC and WMC, wheat early and medium maturity class, respectively) and year, and their interactions.

\begin{tabular}{|c|c|c|c|c|c|c|c|c|c|}
\hline $\begin{array}{l}\text { Treatments and } \\
\text { ANOVA effects }\end{array}$ & Grain yield & Abg. biomass & Spikes $\mathbf{m}^{-2}$ & Grains spike $^{-1}$ & TKW & HI & $\mathbf{W U E}_{\mathbf{b}}$ & $\mathbf{W U E}_{\mathbf{y}}$ & NUE \\
\hline & -- $\mathrm{kg} \mathrm{ha}^{-1}--$ & $--\mathrm{g} \mathrm{m}^{-2}--$ & & & -- g-- & & $--\mathrm{kg} \mathrm{ha}^{-1} \mathrm{~mm}^{-1}--$ & $--\mathrm{kg} \mathrm{ha}^{-1} \mathrm{~mm}^{-1}-$ & -- $\mathrm{kg} \mathrm{ha}^{-1} \mathrm{~kg} \mathrm{~N}^{-1}--$ \\
\hline D1 (October) & $1183 \mathrm{~b} \dagger$ & $570 \mathrm{~b}$ & 322 & $26 \mathrm{~b}$ & $30 \mathrm{a}$ & 0.43 & 19 & 4.0 & $7.2 \mathrm{~b}$ \\
\hline D2 (November) & $1572 \mathrm{a}$ & $732 \mathrm{a}$ & 349 & $33 \mathrm{a}$ & $27 \mathrm{~b}$ & 0.45 & 20 & 4.4 & $10.1 \mathrm{a}$ \\
\hline D3 (December) & $1625 \mathrm{a}$ & $656 \mathrm{ab}$ & 335 & $30 \mathrm{a}$ & $25 \mathrm{c}$ & 0.43 & 17 & 4.0 & $10.2 \mathrm{a}$ \\
\hline WMC & $1541 \mathrm{a}$ & 659 & 346 & 30 & $26 \mathrm{~b}$ & 0.44 & $17 \mathrm{~b}$ & 4.3 & $9.9 \mathrm{a}$ \\
\hline WEC & $1379 \mathrm{~b}$ & 647 & 324 & 30 & $29 \mathrm{a}$ & 0.44 & $20 \mathrm{a}$ & 4.0 & $8.4 \mathrm{~b}$ \\
\hline 2009-10 & $2198 \mathrm{a}$ & $907 \mathrm{a}$ & $373 \mathrm{a}$ & $35 \mathrm{a}$ & $32 \mathrm{a}$ & $0.47 \mathrm{a}$ & $16 \mathrm{~b}$ & $3.9 \mathrm{~b}$ & $13.6 \mathrm{a}$ \\
\hline 2010-11 & $1185 \mathrm{~b}$ & $521 \mathrm{~b}$ & $275 b$ & $31 \mathrm{~b}$ & $26 \mathrm{~b}$ & $0.46 \mathrm{a}$ & $22 \mathrm{a}$ & $4.8 \mathrm{a}$ & $6.0 \mathrm{c}$ \\
\hline 2011-12 & $997 \mathrm{c}$ & $532 \mathrm{~b}$ & $358 \mathrm{a}$ & $24 \mathrm{c}$ & $24 \mathrm{c}$ & $0.39 \mathrm{~b}$ & $18 \mathrm{~b}$ & $3.7 \mathrm{~b}$ & $7.8 \mathrm{~b}$ \\
\hline D1-WMC & $1393 \mathrm{a}$ & 617 & 337 & $30 \mathrm{~b}$ & 29 & $0.45 \mathrm{a}$ & 19 & 4.5 & 8.7 \\
\hline D2- WMC & $1576 \mathrm{a}$ & 737 & 366 & $31 \mathrm{ab}$ & 26 & $0.45 \mathrm{ab}$ & 18 & 4.3 & 10.4 \\
\hline D3-WMC & $1654 \mathrm{a}$ & 622 & 335 & $29 \mathrm{~b}$ & 24 & $0.42 \mathrm{bc}$ & 16 & 4.1 & 10.7 \\
\hline D1-WEC & $973 \mathrm{~b}$ & 524 & 307 & $23 \mathrm{c}$ & 31 & $0.42 \mathrm{c}$ & 19 & 3.5 & 5.8 \\
\hline D2- WEC & $1568 \mathrm{a}$ & 728 & 332 & $35 \mathrm{a}$ & 29 & $0.45 \mathrm{ab}$ & 22 & 4.5 & 9.7 \\
\hline D3- WEC & $1596 \mathrm{a}$ & 691 & 334 & $32 \mathrm{ab}$ & 26 & $0.44 \mathrm{abc}$ & 19 & 4.0 & 9.6 \\
\hline ANOVA & \multicolumn{9}{|c|}{ P-values } \\
\hline Sowing date (SD) & 0.004 & 0.013 & 0.277 & 0.001 & $<0.001$ & 0.228 & 0.254 & 0.323 & 0.003 \\
\hline Maturity class (C) & 0.008 & 0.791 & 0.122 & 0.913 & $<0.001$ & 0.377 & 0.028 & 0.153 & 0.040 \\
\hline Year $(\mathrm{Y})$ & $<0.001$ & $<0.001$ & $<0.001$ & $<0.001$ & $<0.001$ & $<0.001$ & 0.001 & $<0.001$ & $<0.001$ \\
\hline $\mathrm{SD} \times \mathrm{C}$ & 0.009 & 0.307 & 0.566 & 0.010 & 0.689 & 0.012 & 0.753 & 0.089 & 0.426 \\
\hline SD x Y & $<0.001$ & $<0.001$ & $<0.001$ & $<0.001$ & 0.001 & 0.006 & $<0.001$ & $<0.001$ & $<0.001$ \\
\hline C x Y & 0.025 & 0.022 & 0.002 & 0.536 & 0.042 & 0.615 & 0.035 & 0.136 & 0.505 \\
\hline SD $x \mathrm{C} \times \mathrm{Y}$ & 0.055 & 0.922 & 0.366 & 0.179 & 0.001 & 0.128 & 0.884 & 0.223 & 0.631 \\
\hline
\end{tabular}

$\dagger$ For a given variable, different letters indicate significant differences between treatments at $P<0.05$ (LSD test). 

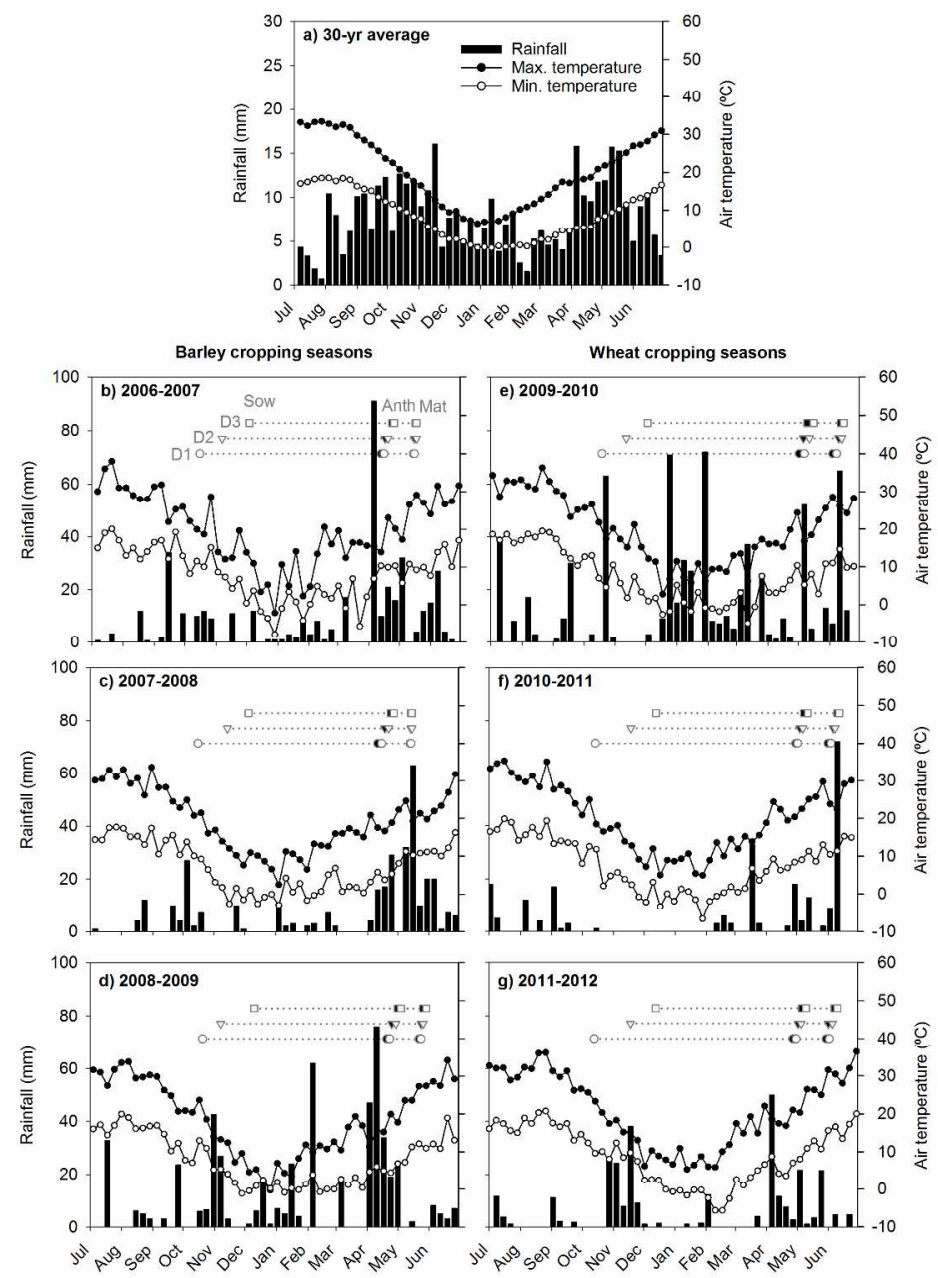

Date

Date

$274 \times 287 m m(300 \times 300$ DPI $)$ 


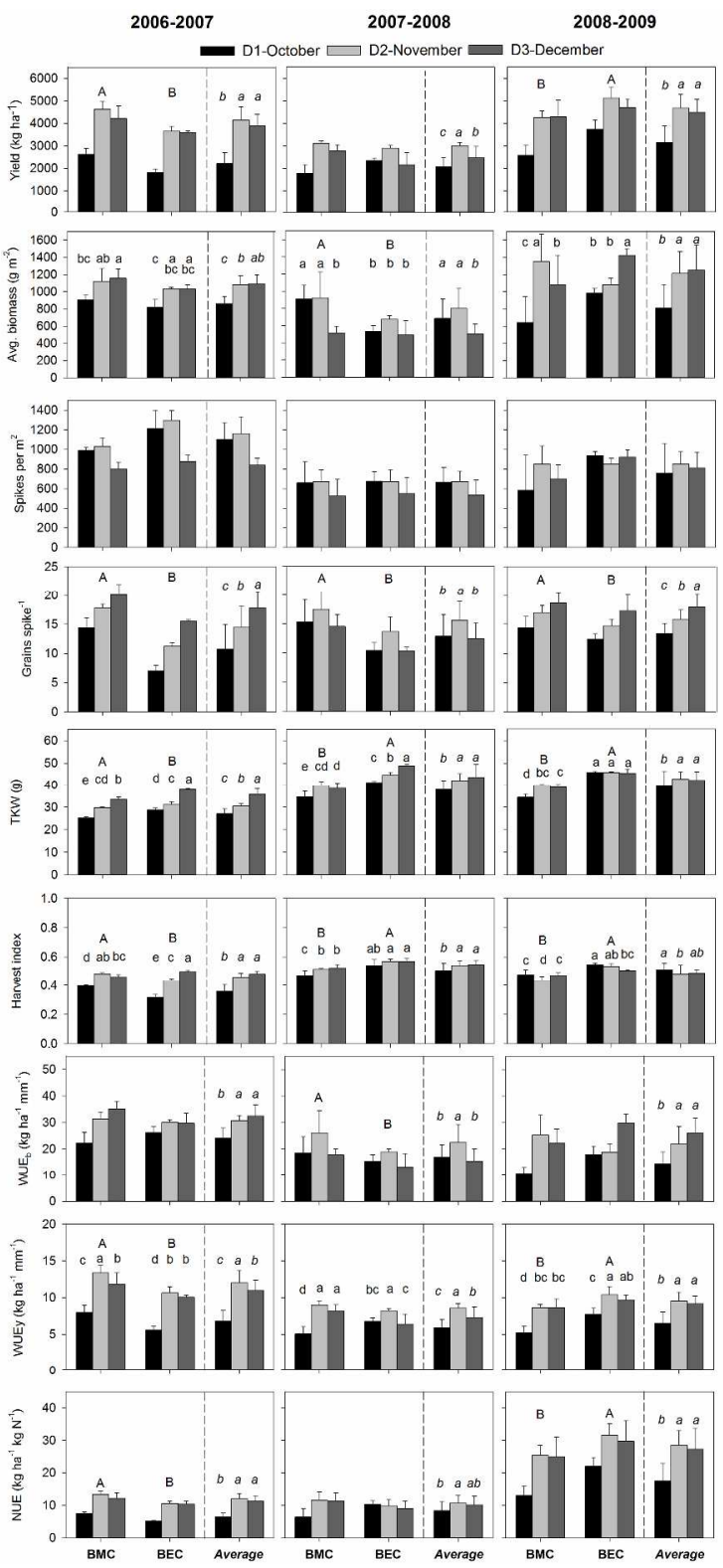

$242 \times 438 \mathrm{~mm}(300 \times 300$ DPI $)$ 


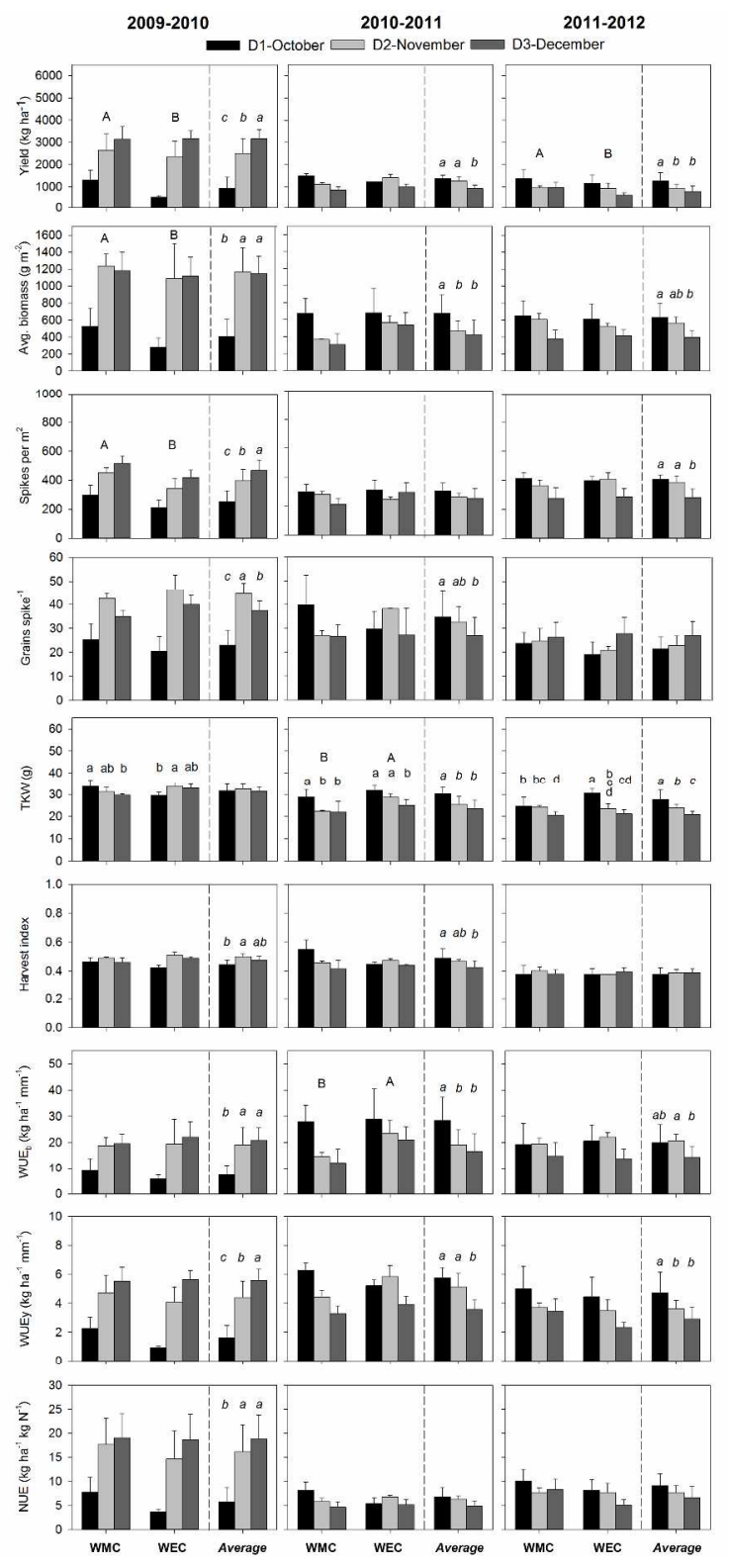

$247 \times 442 \mathrm{~mm}(300 \times 300$ DPI $)$ 

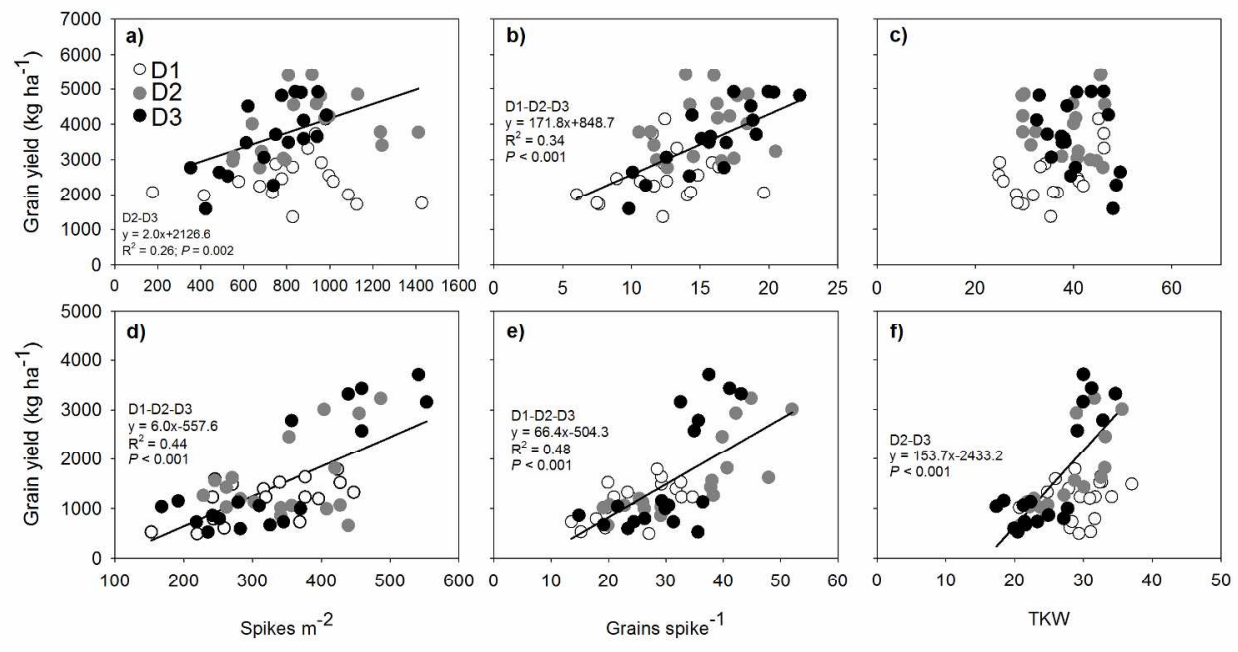

$223 \times 131 \mathrm{~mm}(300 \times 300$ DPI $)$ 